\title{
DEPOIMENTO
}

\section{Regina Vinhaes Gracindo: uma trajetória de vida preciosa}

São muitas as faces de Regina Vinhaes Gracindo. Neste textohomenagem, teço as minhas escolhas, a partir do lugar privilegiado a que me alçou nossa amizade. Começo referindo-me à sua formação acadêmica. Em sua primeira incursão pelos estudos universitários, Regina optou pelo campo do Direito e frequentou as aulas da Faculdade de Direito da Universidade de Brasília (UnB) nos tempos em que o Brasil estava mergulhado nas brumas da ditadura militar. A marca dessa opção, apesar de terem durado pouco tempo, dado que a atração pelo ofício de professora se revelou um apelo mais forte em sua vida, nunca a abandonou e se configurou como um lastro fundamental para sua visão da justiça. em todas as áreas em que atuou.

Seus interesses acadêmicos têm um ponto propulsor na graduação em Pedagogia, na UnB. Dessa época, como bem testemunhou o mestre Benno Sander, que foi seu professor, Regina se destacava como aluna brilhante. Continua seus estudos no Mestrado em Educação, na UnB, e ingressa no doutorado em Educação na Faculdade de Educação da Universidade de São Paulo. Sua tese de doutorado, defendida em 1993, revela a intelectual comprometida com as questões candentes da política educacional brasileira e inaugura um veio de estudos que outros seguirão: a temática dos partidos políticos e educação. Sua tese, publicada com o título A Concepção dos Partidos Políticos e Educação, logo se tornou referência importante nos estudos da área. Em sua maturidade intelectual, decidiu ampliar suas pesquisas desenvolvendo o pós-doutoramento na prestigiada École des Hautes Études em Sciences Sociales, na cidade-luz, que tanto amava.

Sua atividade profissional exerceu-a de modo exemplar. Muito jovem, envolveu-se entusiasticamente com a Educação Básica, primando, de forma séria, comprometida e responsável, pela qualidade do ensino e da gestão em escolas públicas e unidades educativas da Fundação Educacional do Distrito Federal. Mostrou seu carisma e competência nas atividades que desenvolveu como mestra e dirigente escolar. Essa experiência profissional lhe deu o lastro principal para os futuros estudos acadêmicos que desenvolveu ao longo da vida na área de política e gestão educacional.

Tal experiência mostrou-se inspiradora da sua inserção consciente nos inúmeros movimentos da sociedade civil dos quais participou em prol de uma educação pública, laica, gratuita, democrática e de qualidade referenciada pelo social. Citarei apenas algumas participações dentre as inúmeras em que demonstrou 
garra e compromisso cotidiano em favor das práticas democráticas e da justiça social. Regina emprestou seu talento e sua disposição juvenil para participar, de forma ativa, das associações acadêmico-científicas do campo da educação. Assim, foi eleita presidenta, por duas gestões, da Associação Nacional de Política e Administração da Educação (Anpae), tendo influenciado definitivamente a aproximação dessa entidade com os movimentos pela gestão democrática, seja no Brasil, seja na América ibérica. Na Associação Nacional de Pós-Graduação e Pesquisa em Educação (ANPEd), a mais importante de nossas entidades científicas no campo da educação, participou da diretoria em dois períodos de nossa gestão (2005-2009) e atuou de forma comprometida no desenvolvimento de pesquisas envolvendo a Educação de Jovens e Adultos.

Durante sua presidência, fincou as raízes do intenso e profícuo intercâmbio acadêmico com intelectuais portugueses e espanhóis que integravam a Sociedade Portuguesa de Ciências da Educação, o Fórum Português de Administração Educacional e o Fórum Europeu de Administradores da Educação, da Espanha. Esse intercâmbio resultou em sucessivos eventos internacionais que se realizaram em terras de Portugal, Brasil e Espanha, estabelecendo uma tradição de encontros científicos congregando gestores, profissionais da educação, pesquisadores e estudantes em torno de temáticas cruciais do nosso tempo. Deu grande contribuição à produção dos principais documentos das duas edições da Conferência Nacional de Educação, de 2010 e de 2014, como já havia feito em atividades do Fórum em Defesa da Escola Pública.

Regina dedicou-se com grande afinco, como Coordenadora, à renovação da Pós-Graduação em Educação da Faculdade de Educação da UnB e teve papel relevante na formação de novos mestres e doutores cujas produções orientou e que, hoje, por sua vez, ocupam lugares de destaque no sistema educacional brasileiro. Seus livros, artigos e textos integram a bibliografia obrigatória dos cursos de graduação e de pós-graduação na área de política e gestão da educação.

Afirmo, finalizando esta homenagem, que Regina, carioca com alma brasiliense - que ficou tão feliz quando recebeu o título de Cidadã Honorária da Câmara Legislativa do Distrito Federal - nos últimos anos de sua atuação profissional, juntou as duas extremidades de uma trajetória singular: de um lado, exerceu com coragem e com certa dose de heroísmo o difícil caminho da titularidade da gestão da Educação Básica no Distrito Federal e, de, outro lado, na condição de conselheira da Câmara da Educação Básica do Conselho Nacional de Educação, contribuiu para o aperfeiçoamento do ordenamento legal da Educação Básica no Brasil.

Com emoção, concluo este texto, lembrando a letra de uma música do eterno Gonzaguinha, que Regina cantava, com graça e voz aveludada, dedilhando 
o violão, numa noite de confraternização, ao término de uma jornada de trabalho, na Unesco, em Santiago do Chile, nos idos de 1990:

\section{Eu fico com a pureza da resposta das crianças: \\ É a vida, é bonita e é bonita. \\ Viver e não ter a vergonha de ser feliz.}

Cantar... (E cantar e cantar...) A beleza de ser um eterno aprendiz.

$$
\text { Ab! Meu Deus }
$$

Eu sei... (Eu sei...) Que a vida devia ser bem melhor e será

Mas isso não impede que eu repita

É bonita, é bonita e é bonita.

Salve, Regina!

Recife, abril de 2016

Márcia Angela Aguiar 